\title{
エテルカルセチド塩酸塩投与プロトコールの作成
}

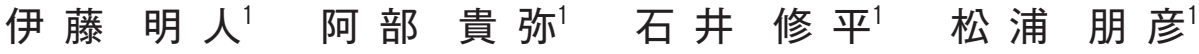 \\ 杉村 淳 ${ }^{1}$ 佐々木 成幸 $^{2}$ 高澤 由美子 ${ }^{2}$ 加 藤 哲 夫 $^{2}$ \\ 小 原 航 \\ 1岩手医科大学泌尿器科学講座 \\ 楽山会せいてつ記念病院透析センター
}

キーワード：血液透析，二次性副甲状腺機能立進症，エテルカルセチド塩酸塩

〈要旨〉

エテルカルセチド塩酸塩（Etel）開始後の増減については，各主治医の判断となる．そのため複数の医師による透 析管理が行われている施設では, 同一施設内においても Etel による二次性副甲状腺機能克進症（SHPT）の管理に 異なりが生じる可能性がある. 今回, 同一施設内での Etel による SHPT 管理に異なりが生じないように Etel 投与 プロトコールを作成し，その効果について検討した．プロトコールは Etel 国内第III相長期投与試験に準じ作成し た. 22 名を対象とし, 研究期間は Etel 開始時から開始後 28 週間目までとした. 研究期間内に, 他因子での死亡 2 名を含め 5 名が脱落したが, 17 名が研究を完遂した. Etel の投与量は $5 \mathrm{mg}$ から, 終了時には $4.4 \pm 1.7 \mathrm{mg}$ に有意 に低下した $(p=0.0084)$. また intact-PTH が $240 \mathrm{pg} / \mathrm{mL}$ 以下に管理された患者数は 22 名中 12 名（54.5\%）から終 了時には $15 / 17$ 例 $(88.2 \%)$ と有意に増加した $(p=0.0238)$. 今回作成したプロトコールでは明らかな副作用の出 現もなく，効率的にSHPT の管理が可能であった.

\section{Protocol for etelcalcetide hydrochloride treatment}

Akito Ito', Takaya Abe ${ }^{1}$, Shuhei Ishii', Tomohiko Matsuura', Jun Sugimura', Nariyuki Sasaki², Yumiko Takasawa², Tetsuo Kato², Wataru Obara ${ }^{1}$

${ }^{1}$ Department of Urology, Iwate Medical University

${ }^{2}$ Dialysis Center, Seitetsu Memorial Hospital

Keywords: hemodialysis, etelcalcetide hydrochloride, secondary hyperparathyroidism

$\langle$ Abstract〉

After the initial administration of etelcalcetide hydrochloride (Etel), its dosage might be adjusted depending on the attending physician's view. Therefore, at dialysis facilities, where patients are managed by multiple doctors, the management of secondary hyperparathyroidism (SHPT) with Etel can take many different courses. In this study, an Etel administration protocol was devised to prevent variations in Etel-based SHPT management within the same dialysis facility, and its effects were examined. The protocol was devised in accordance with the findings of domestic phase III trials of Etel. Twenty-two subjects were enrolled. The study period lasted for 28 weeks, starting from the administration of the first dose of Etel. During the study, 5 subjects dropped out, including 2 patients who died because of other factors, and so 17 subjects completed the study. The mean dose of Etel decreased significantly from $5 \mathrm{mg}$ at the start of the study to $4.4 \pm 1.7 \mathrm{mg}$ at the end of the study $(p=0.0084)$. In addition, by the end of the study the proportion of patients whose intact-parathyroid hormone levels were controlled at $\leq 240 \mathrm{pg} / \mathrm{mL}$ had significantly increased from $12(54.5 \%)$ out of 22 subjects to 15 (88.2\%) out of 17 subjects ( $p=0.0238$ ). No new side effects developed during the study period. This Etel administration protocol might enable physicians to manage and control SHPT more effectively.

伊藤 明人 岩手医科大学泌尿器科学講座 T 020-8505 岩手県盛岡市内丸 19-1

Akito Ito Tel：019-651-5111 Fax：019-623-1527 E-mail：aito@iwate-med.ac.jp

〔受付日：2018 年 4 月 4 日, 受理日：2019 年 1 月 29 日〕 


\section{緒言}

透析患者の死亡原因の $1 / 3$ は, 心血管系合併症であ $\eta^{1)}$, 動脈硬化が強く関与している。この透析患者の 動脈硬化の主な病因として, 高リン $(\mathrm{P})$ 血症と二次性 副甲状腺機能充進症 (secondary hyperparathyroidism：SHPT）があげられ，慢性腎臟病に伴う骨・ミネ ラル代謝異常 (chronic kidney disease-mineral and bone disorder：CKD-MBD) の管理が重要である。わ が国の CKD-MBD 診療ガイドラインが作成されてお り, 血清 P 濃度の管理目標值 $3.5 \sim 6.0 \mathrm{mg} / \mathrm{dL}$, 補正力 ルシウム $(\mathrm{Ca})$ 濃度の管理目標值 $8.4 \sim 10.0 \mathrm{mg} / \mathrm{dL}$ が 推奨されている ${ }^{2)}$. また Taniguchi ら ${ }^{3)}$ は 128,125名の わが国の患者デー夕の解析を行い, 血清 intact-PTH (i-PTH) 值が高いほど先述のガイドラインにおける血 清 $\mathrm{P}$ 抢よび $\mathrm{Ca}$ 值の目標值同時達成のオッズ比が低下 することを報告しており, 血清 P およびCa のコント ロールだけでなく, i-PTH のコントロールも重要と考 えられる. 近年, 高リン血症に対しさまざまなカルシ ウム $(\mathrm{Ca})$ 非含有リン吸着薬が使用できるようになっ た。また SHPT に対し $\mathrm{Ca}$ 受容体作動薬（CaR）が使 用できるようになった.

2004 年に経口 $\mathrm{CaR}$ 製剤であるシナカルセ卜塩酸塩 (cinacalcet：Cina) が米国で市販された. Cina と低用

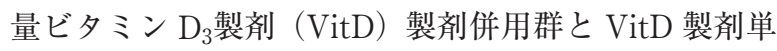
独投与群の二群間において血管と心臟弁の石灰化を評 価した研究 (ADVANCE study $)^{4}$ や Cina 投与群とフ ラセボ投与群において SHPTを合併した患者の死亡あ るいは非致死的心血管イベントに与える影響を評価し た研究 $(\text { EVOLVE study })^{5}$ など Cinaに関する大規模 な研究が行われてきた。

ADVANCE study ${ }^{4}$ では, 試験開始後 52 週目におい て両群間で主要評価項目である全冠動脈における石灰 化スコアに有意差を認めなかったがCina と低用量 VitD 製剂併用群において低い傾向がみられ，大動脈 弁の石灰化スコアや Ca volume スコアの変化率では 有意に進行の抑制が認められた。ささらに post-hoc 解 析6)では Cina と低用量 VitD 製郕併用群において全冠 動脈と大動脈弁における石灰化スコアおよび $\mathrm{Ca}$ volume スコアの変化率で有意に進行の抑制が認められ, Cina と低用量 VitD 製剤併用群は冠動脈石灰化に対し て有効性のある治療法であることが示唆された。また EVOLVE study ${ }^{5)}$ では, 主要評価項目である複合エン ドポイントは未調整ITT 解析において，Cina 群では $7 \%$ の低下を認めたが有意な改善を認めなかった。 post-hoc 解析?) では, Cina 群は初回非アテローム性動 脈硬化イベント発生リスクが $16 \%$ の低下を認め, また サブ解析8)では, Cina の投与はカルフィラキスの発現 の抑制を認めた。これらの研究などより Cina は PTH のみならず $\mathrm{Ca}, \mathrm{P}$ も低下させることより心血管系合併 症の予防効果が示唆されている.

その一方, Cina は経口剤のためアドヒアランス不良 などの問題点を有している. 2017 年 2 月に世界初の静 注 CaR であるエテルカルセチド塩酸塩（Etel）が市販 され，透析患者の服薬の負担を軽減するなど注射薬の 特性を生かした SHPT の管理が可能となり, さらなる SHPT の治療成績の向上が期待される.

\section{I . 目的}

Etel の添付文書上，開始用量については明確に記載 されているが，増減については明らかにされておら ず9), 各主治医の判断となる. また大規模透析施設で は，複数の医師による透析室管理が行われていること が多く，同一施設内に扔いても EtelによるSHPT管理 に異なりが生じる可能性がある。

今回，同一施設内に扔いて EtelによるSHPT管理に 異なりが生じないように Etel 投与プロトコールを作 成し，臨床的に評価した。

\section{II. 方 法}

月・水・金の午前中に外来血液透析を受けている患 者で, SHPT に対して1か月以上同量のCina を内服し ている患者で, 内服数を減らす目的にて Cinaから Etel に変更予定の患者のうち, 本研究について承諾が得ら れた 22 名を対象とした，研究期間は，Etel 開始時か ら開始後 28 週間目までとした。

Etel 投与プロトコールは, 国内第 III 相長期投与試験 に準じ9) (表 1),

壃量判定基準

1）同じ用量を 4 週間以上維持している かつ

2）血清 $\mathrm{i}-\mathrm{PTH}$ 濃度 $\geqq 240 \mathrm{pg} / \mathrm{mL}$ ，かつ補正 Ca 濃 度 $\geqq 8.4 \mathrm{mg} / \mathrm{dL}$

減量判定基準

1）血清 $\mathrm{i}-\mathrm{PTH}$ 濃度 $<60 \mathrm{pg} / \mathrm{mL}$ に低下した場合 あるいは

2）透析前補正 $\mathrm{Ca}<8.4 \mathrm{mg} / \mathrm{dL}$ ただし，血清 i-PTH 濃度 $\geqq 240 \mathrm{pg} / \mathrm{mL}$ の場合 は VitDの開始あるいは増量を検討する。 
表 1 Protocol of etelcalcetide hydrochloride



注 1）血清リン值のコントロールが第一とする.

注 2) $2.5 \mathrm{mg}$ ずつ増隇する.

休薬判定基準

1）透析前補正 $\mathrm{Ca}$ 濃度 $<7.5 \mathrm{mg} / \mathrm{dL}$ の場合 ただし，血清 i-PTH 濃度 $\geqq 240 \mathrm{pg} / \mathrm{mL}$ の場合，

VitDの開始あるいは増量を検討する.

以上のように作成し, 臨床研究を行った。ただし, 血清 P 值のコントロール $(3.5 \sim 6.0 \mathrm{mg} / \mathrm{dL})$ を第一目

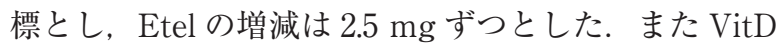
の開始および増減に関しては，新たに VitD を開始す る場合はマキサカルシトール $2.5 \mu \mathrm{g} \times 3$ 回/週から開始 した。また増減に関しては，マキサカルシトールの場 合 1 回量を $2.5 \mu \mathrm{g}$ ずつ増減し, カルシトリオールの場 合 1 回量を $0.5 \mu \mathrm{g}$ ずつ増減した。 また透析液は, キン ダリー 3 号液（透析液 $\mathrm{Ca}^{++}$濃度 : $2.5 \mathrm{mEq} / \mathrm{L}$ ）を使用 した.

開始後 4 週間後までは毎週，それ以後 2 週間ごとに 28 週間後まで採血を行った。採血項目は，月曜日血液 透析開始直前に, アルブミン (Alb), Ca, P, i-PTH を測定した。 なお補正 Caは, Payneの式10)にて求めた.

評価項目として，開始時および開始後 28 週目におけ る Etel 投与量, i-PTH および補正 Ca について検討し た。 また慢性腎臓病に伴う骨・ミネラル代謝異常の 診療ガイドライン」に2 における i-PTHの管理目標值 (60〜 $240 \mathrm{pg} / \mathrm{mL})$ に管理された患者数についても検討 した.

統計解析は, 開始時および開始後 28 週目の比較は ウイルコクソン符号付順位和検定を用い，また目標值 に管理された患者数の比較は $\chi^{2}$ 検定を用いた. $p<$ 0.05 を有意水準とし, 值は平均值 \pm 標準偏差にて表示 した.

なお，本研究は医療法人楽山会せいてつ記念病院倫 理委員会にて承認を得た(承認番号 012 号)。またすべ

\begin{tabular}{|c|c|}
\hline 性別 & 22 \\
\hline $\mathrm{M} / \mathrm{F}$ （人） & $11 / 11$ \\
\hline 年齢（歳） & $62.2 \pm 12.9$ \\
\hline 平均透析歴 (年) & $13.0 \pm 6.6$ \\
\hline 平均 DW（kg） & $60.5 \pm 15.6$ \\
\hline 平均シナカルセト投与量 (mg/毎 $\mathrm{HD})$ & $23.7 \pm 7.6$ \\
\hline \multicolumn{2}{|l|}{ 開始時ビタミン $\mathrm{D}_{3}$ 製剤（人） } \\
\hline カルシトリオール $1.5 \mu \mathrm{g} /$ 週 & 1 \\
\hline カルシトリオール $2.0 \mu \mathrm{g} /$ 週 & 2 \\
\hline カルシトリオール $3.0 \mu \mathrm{g} /$ 週 & 3 \\
\hline マキサカルシトール $2.5 \mu \mathrm{g} /$ 週 & 2 \\
\hline マキサカルシトール $5.0 \mu \mathrm{g} /$ 週 & 3 \\
\hline マキサカルシトール $7.5 \mu \mathrm{g} /$ 週 & 5 \\
\hline マキサカルシトール $15 \mu \mathrm{g} /$ 週 & 3 \\
\hline 投薬なし & 3 \\
\hline \multicolumn{2}{|l|}{ 原疾患 (人) } \\
\hline 糖尿病性腎症 & 11 \\
\hline 慢性系球体腎炎 & 6 \\
\hline 腎硬化症 & 2 \\
\hline その他，不明 & 3 \\
\hline
\end{tabular}

ての対象患者において書面により同意を得た.

\section{III. 結 果}

\section{1. 患者背景 (表 2)}

対象患者の性別は男性 11 例，女性 11 例であり，平 均年齢 $62.2 \pm 12.9$ 歳であった。主な原疾患は糖尿病性 腎症 11 例, 慢性糸球体腎炎 6 例, 腎硬化症 2 例, その 他・不明 3 例であった。平均透析歴は $13.0 \pm 6.6$ 年で あった。開始時の平均 dry weight (DW) は $60.5 \pm 15.6$ $\mathrm{kg}$, 平均 Cina 投与量は $23.7 \pm 7.6 \mathrm{mg}$ /毎日であった. また開始時に静注 VitD 製剤は 22 名中 19 名に投薬さ れており，その内訳は，カルシトリオール $1.5 \mu \mathrm{g} /$ 週 1 名, $2.0 \mu \mathrm{g} /$ 週 2 名, $3.0 \mu \mathrm{g} /$ 週 3 名, マキサカルシトー ル $2.5 \mu \mathrm{g}$ /週 2 名, $5.0 \mu \mathrm{g}$ /週 3 名, $7.5 \mu \mathrm{g}$ /週 5 名, $15 \mu \mathrm{g} /$ 週 3 名であった。

\section{Etel 投与量の推移}

Etel を毎回の透析終了時に $5 \mathrm{mg}$ を経静脈的に投与 開始し, その後はプロトコールに従い増減を行った。 研究期間内に 5 名が脱落 (死亡 $: 2$ 名, 転出 : 1 名, Ca および i-PTH：1名）し，17 名が研究を完遂した. この 17 名の開始後 28 週間目における Etel 投与量は, 週 $7.5 \mathrm{mg} \times 3$ 回投与された患者 2 名, 週 $5.0 \mathrm{mg} \times 3$ 回 投与された患者は 9 名, 週 $2.5 \mathrm{mg} \times 3$ 回投与された患 者は 6 名であった(図 1). Etel の投与量は $5 \mathrm{mg}$ から, 開始後 28 週間目には $4.4 \pm 1.7 \mathrm{mg}$ に有意に低下した $(p=0.0084)$ (図 2). 


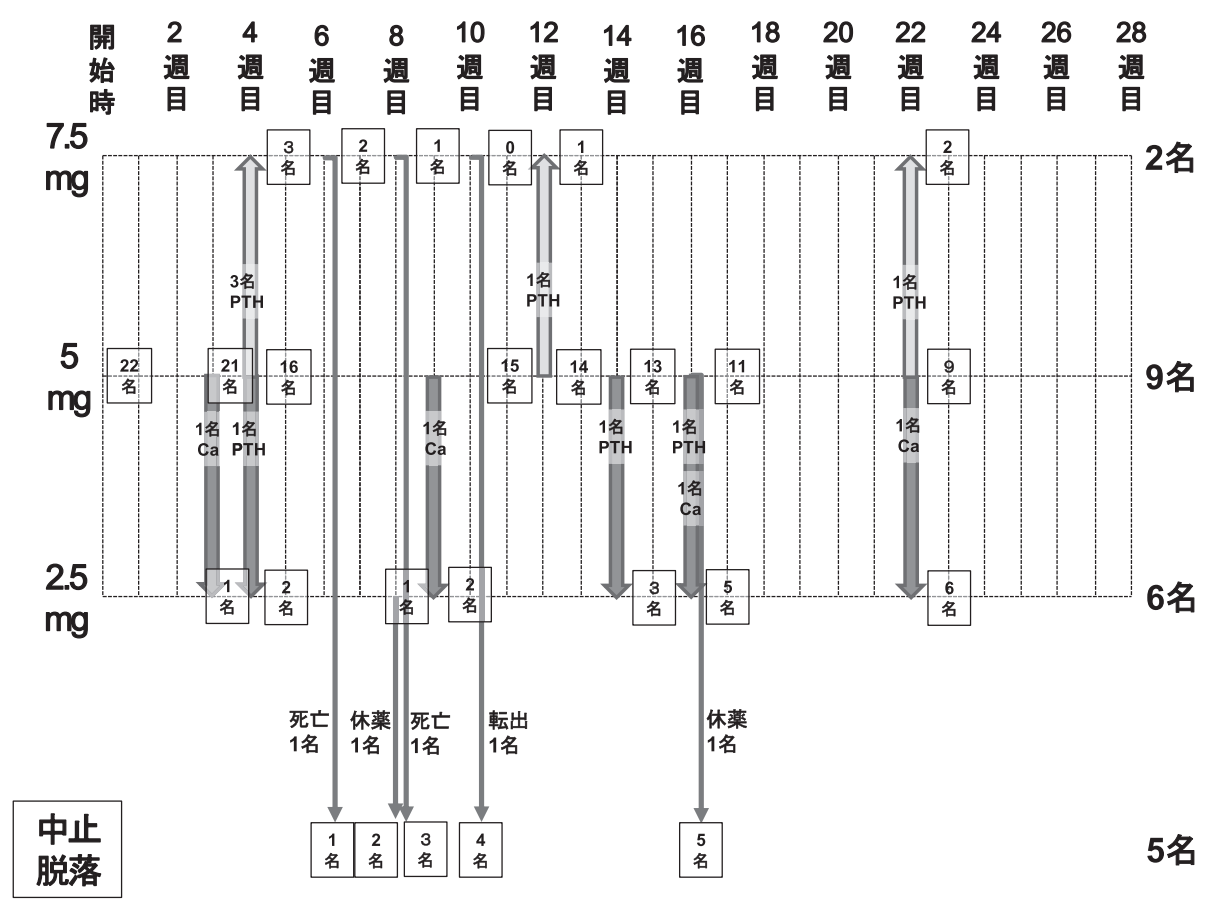

図 1 Patient flow diagram

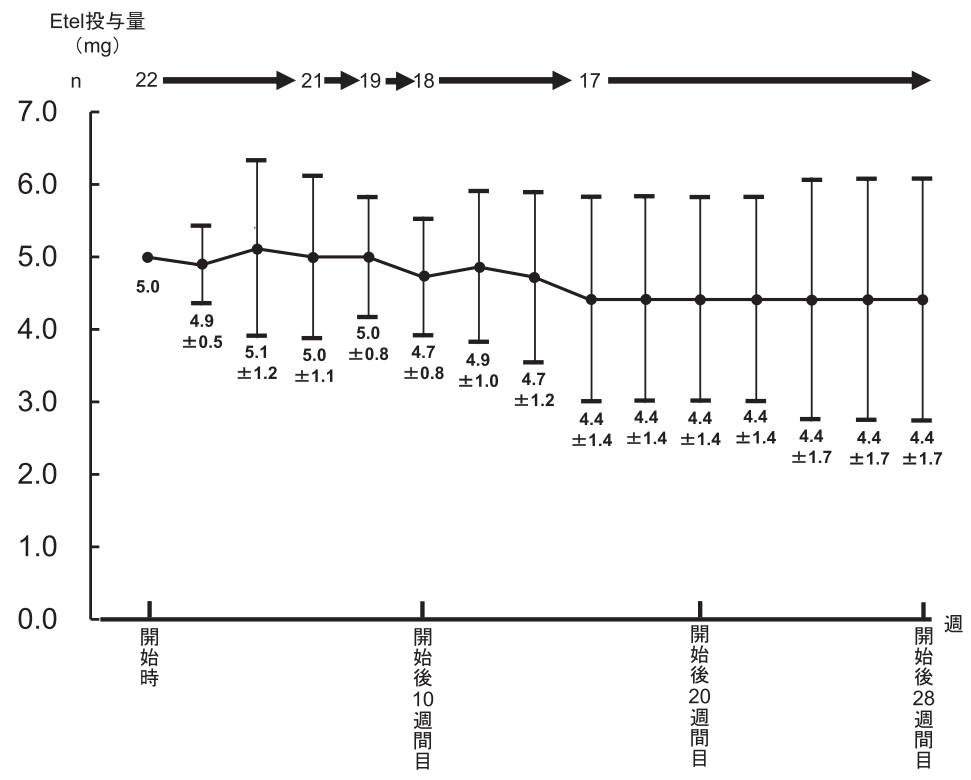

図 2 Time course change of etelcalcetide dose

3. VitD 投与量の推移 (表 3)

研究を完遂しえた 17 名において, 開始時と研究終了 時の 2 点間での $V i t D$ 投与量を比較すると, 8 名におい て投与量の増加を認めた.

\begin{tabular}{|c|c|}
\hline 開始時 & 終了時 \\
\hline \multicolumn{2}{|c|}{ カルシトリオール $(\mu \mathrm{g} /$ 週 $)$} \\
\hline 1.5 & 3 \\
\hline 2 & 2 \\
\hline 2 & 3 \\
\hline 3 & 4.5 \\
\hline 3 & 4.5 \\
\hline \multicolumn{2}{|c|}{ マキサカルシトール（ $\mu \mathrm{g} /$ 週 } \\
\hline 2.5 & 2.5 \\
\hline 5 & 5 \\
\hline 5 & 10 \\
\hline 7.5 & 7.5 \\
\hline 7.5 & 7.5 \\
\hline 7.5 & 7.5 \\
\hline 7.5 & 10 \\
\hline 7.5 & 15 \\
\hline 15 & 15 \\
\hline 15 & 15 \\
\hline 15 & 15 \\
\hline 0 & 22.5 \\
\hline
\end{tabular}

\section{4. i-PTH および補正 Ca 值の推移}

開始時の i-PTH は $256.14 \pm 117.86 \mathrm{pg} / \mathrm{mL}$ であり， 開始後 28 週間後の $\mathrm{i}-\mathrm{PTH}$ は $137.82 \pm 81.10 \mathrm{pg} / \mathrm{dL}$ に有 意に低下した（ $p=0.0262 ）$ （図 3）.

Etel 開始時の補正 Ca值は $9.35 \pm 0.68 \mathrm{mg} / \mathrm{dL}$ であり，

5. i-PTH 管理目標値（240 pg/mL 以下）達成率 i-PTH が $240 \mathrm{pg} / \mathrm{mL}$ 以下に管理された患者数は 22 名中 12 名（54.5\%）であったが，開始後 28 週間後に は $15 / 17$ 例（88.2\%）と増加した（ $p=0.0237 ）$ (図 3). 開始後 28 週間後 $9.08 \pm 0.48 \mathrm{mg} / \mathrm{dL}$ であった（図 4). 


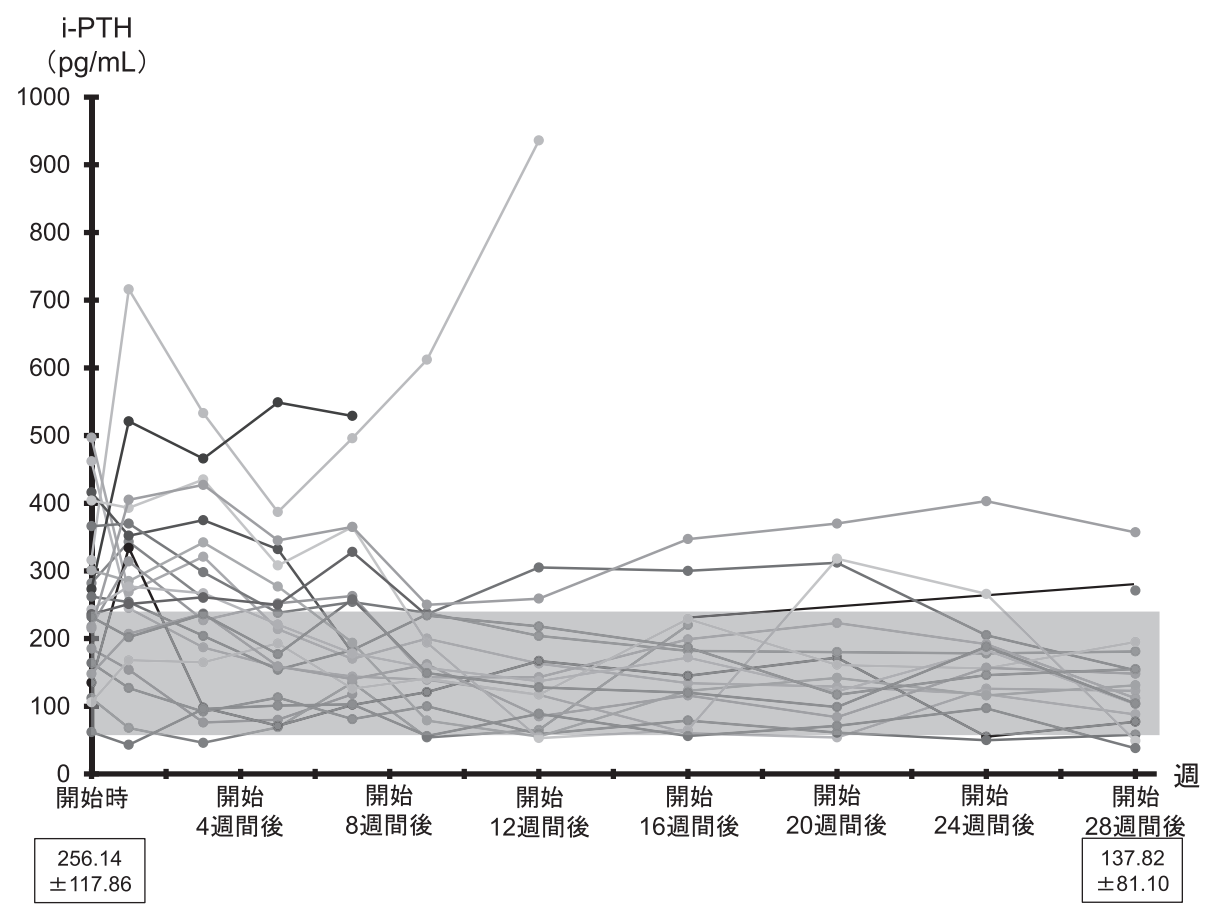

図 3 Time course change of serum i-PTH

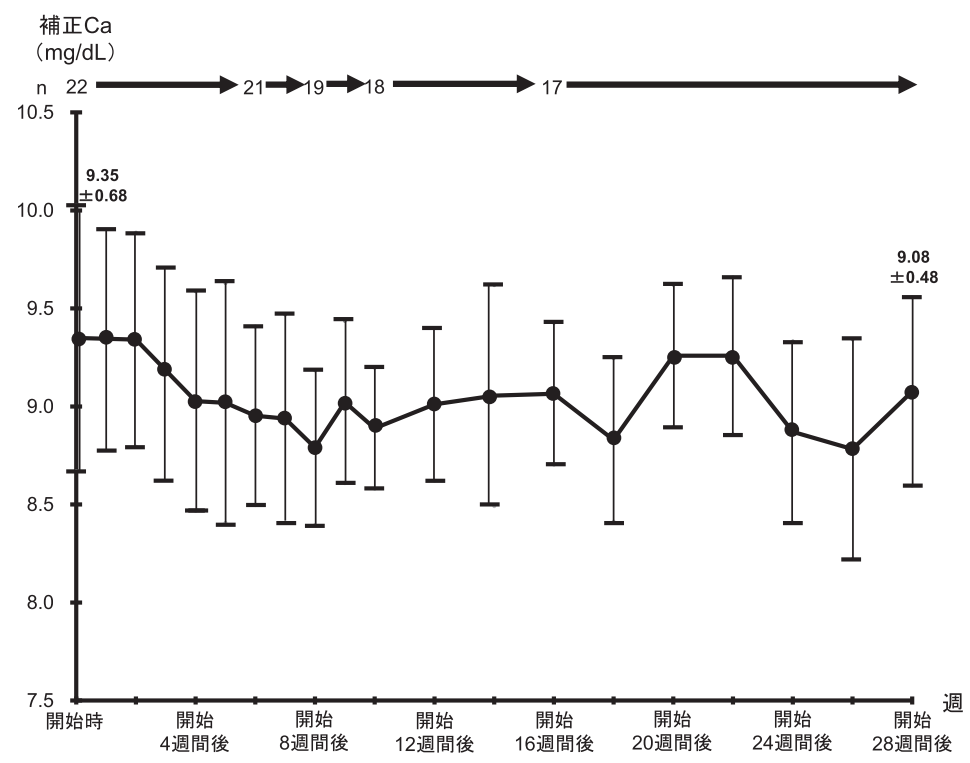

図 4 Time course change of corrected calcium

\section{IV. 考 察}

同一施設内において，同じ基準により Etelによる SHPT 管理が可能な Etel 投与プロトコールを作成し た. 添付文書上 ${ }^{9)} 「$ 増量する場合には増量幅を $5 \mathrm{mg}$ と し，4 週間以上の間隔をあけて行うこと．ただし，血 清 Ca 濃度や PTH が管理目標值を下回らないように, $2.5 \mathrm{mg}$ の増量も考慮すること.」とされている. その ため, 本プロトコールでは低カルシウム血症の危険性
を危惧し, 本プロトコールの増量幅を $2.5 \mathrm{mg}$ とした. 本プロトコールでは低カルシウム血症にて脱落したの は 22 名中 1 名であった（図 1).

本プロトコールでの管理により, Etel の投与量は 5 $\mathrm{mg}$ から, 研究終了時には $4.4 \pm 1.7 \mathrm{mg}$ と低下した（図 2). 開始時の Cina 投与量の平均が $23.7 \pm 7.6 \mathrm{mg}$ であ り, Cina による SHPT の総医療費はレグパラ ${ }^{\circledR} 25 \mathrm{mg}$ （薬価 549.8 円）換算で，各患者 1 週間当たり約 3,649 円であった. Etel 投与開始後 28 週間目の Etel の薬剤 費はパーサビブ® $5 \mathrm{mg}$ （薬価：1,283 円）換算で, 各患 




図 5 Correlation between i-PTH change and cinacalcet dose

者 1 週間当たり約 3,387 円であった。 な抒開始後 28 週 間目の時点で, 補正 $\mathrm{Ca}$ を是正する目的で 17 名中 8 名 において開始時に比べVitD が増量されていた。これ らの VitD 増加分, 約 515 円を加えると開始後 28 週間 目の Etel によるSHPT の総医療費は約 3,902 円とな り，やや高価となった。しかし今回，透析液としてキ ンダリー 3 号液（透析液 $\mathrm{Ca}^{+}{ }^{+}$濃度 $: 2.5 \mathrm{mEq} / \mathrm{L}$ ）を用 いており, $\mathrm{Ca}^{++}$濃度 $2.75 \mathrm{mEq} / \mathrm{L}$ あるいは $3.0 \mathrm{mEq} / \mathrm{L}$ の透析液を用いた場合，これらの差額はなくなる可能 性が考えられた。

「慢性腎臟病に伴う骨・ミネラル代謝異常の診療ガ イドライン」吕におけるi-PTH の管理目標值である 240 $\mathrm{pg} / \mathrm{mL}$ 以下に管理された患者数は, 開始時（Cina 投 与時）の $12 / 22$ 例 (54.5\%) であったが, 研究終了時 には 15/17 例（88.2\%）と増加した $(p=0.024) .683$ 例 を対象とした Etel とCina の二重盲検比較試験では, $\mathrm{i}-\mathrm{PTH}$ の $30 \%$ 減少効果（68.2 vs. $57.7 \%, p<0.001 ）$ 並

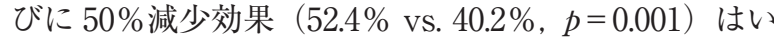
ずれも Etel が有意に優れていたとの海外の報告9)があ り, 同様の結果となった。今回の結果は, 対象群の開 始時の Cina 投与量が $23.7 \pm 7.6 \mathrm{mg} /$ 毎日と少ないこと やCinaのアドヒアランスの問題が影響している可能 性はあるが, Etel はSHPT の強力な治療方法であると 考えられた。

観察期間内に補正 $\mathrm{Ca}$ の低下 1 名, 補正 $\mathrm{Ca}$ および $\mathrm{iPTH}$ の低下 1 名, 転院 1 名, 死亡 2 名, 計 5 名の脱 落症例を認めた. 2 名の死亡症例は Etel 投与開始後約 6 週間後および 8 週間後に発生しており, Etel との関 連が疑われたが, Etel 投与中の補正 Ca は正常範囲内 での推移であり，その他 Etel が誘因と思われる所見を 認めず。また両名とも原疾患が糖尿病性腎症であり， 12 年 8 か月および 18 年 11 か月の長期透析歴を有する
患者であった。また両名とも Etel 投与開始時には下肢 切断および脳梗塞，心筋梗塞の既往歴があったことな どから，死因は Etel 投与ではなく既往歴として有して いた心血管合併症によるものと判断したが，重症の心 血管合併症を有する患者への投与は注意が必要と考え る.

Cina と Etel の副作用発現率については報告 ${ }^{11)}$ が少 なく一定した答えはない．今回の検討では Cina から Etel に変更後に CaR に起因すると思われる消化器症 状など新たな副作用を認めることはなかった。これは 副作用なくCina を投与できていた症例を Etel 投与に 変更したためと考えられ，今後さらなる検討が必要で ある。

添付文書 ${ }^{9)}$ 上, 「通常，成人には，エテルカルセチド として 1 回 $5 \mathrm{mg}$ を開始用量とし, 週 3 回, 透析終了 時の返血時に透析回路静脈側に注入する.」, 「増量す る場合には増量幅を $5 \mathrm{mg}$ とし，4 週間以上の間隔をあ けて行うこと.ただし，血清カルシウム濃度やPTHが 管理目標値を下回らないように, $2.5 \mathrm{mg}$ の増量も考慮 すること.」とされている。 そのため Cina の投与量や 目標体重（DW）によらずEtel $5 \mathrm{mg}$ からの開始とな る。そこで，今回「DW 当たりの Cina 投与量」(Etel 開始時の Cina 投与量を DW で除した值）と「i-PTH の変化率」(Etel 開始後 4 週間目の i-PTH 值を Etel 開 始時の i-PTH で除した值)の関連を検討した。 i-PTH 変化率が $100 \%$ 以上の場合, Cina から Etelに変更した が，i-PTH のコントロールがなされていない場合であ り, 逆に $100 \%$ 以下の場合, Cina から Etelへの変更に より $\mathrm{i}-\mathrm{PTH}$ のコントロールが良好になったことを示 す. Etel 開始後 4 週間経過した場合, i-PTH の值によ り Etelが増加される可能性があるため, 最初の Etel増 量を検討する開始後 4 週間目のデー夕を用いた。また 
本研究では, 今回のプロトコールでは開始後 4 週間目 までに VitD 製剤が開始あるいは増加される可能性が あるが，実際は開始後 8 週間目までは VitD 製剤を変 更した症例は生じなかったため, 今回の評価に VitD 製剂の変更による影響はないと考えられる。「DW 当 たりの Cina 投与量」と「i-PTH の変化率」の間には, 正の相関を認めた $(\mathrm{r}=0.6226, p=0.0066)$ （図 5). 「i-PTH の変化率」 $100 \%$ の場合, Cina と Etel の効果 が同等と考えられる「i-PTH の変化率」100\%を示す $\lceil\mathrm{DW}$ 当たりのCina 投与量」は $0.42 \mathrm{mg} / \mathrm{kg}$ となり, 仮に DW が $60 \mathrm{~kg}$ の患者の場合は Cina $25.2 \mathrm{mg}$ の連日 内服が, Etel $5 \mathrm{mg}$ 週 3 回透析後投与に相当すると考 えられた. Etel と Cinaの二重盲検比較試験 ${ }^{11)}$ では, 初期の Etel と Cina の投与量はそれぞれ $5 \mathrm{mg}$ 週 3 回透 析後静注投与と $30 \mathrm{mg}$ 連日経口投与とされており, 今 回の結果との違いは体格差などが影響したと考える. また本研究での Cina のアドヒアランスに関しては, 患者への聞き取りのみであり, Cina のアドヒアランス が不確定な部分が開始時i-PTH に影響した可能性も あると考える。

本来であれば, SHPT の管理は Etel および VitD の 増減を組み合わせて行うべきである，本研究では補正 $\mathrm{Ca}$ 值が $11.0 \mathrm{mg} / \mathrm{dL}$ 超えることがなかったが, $\mathrm{Ca}$ の 上昇による VitDの減量について考慮されていない点, $\mathrm{i}-\mathrm{PTH}$ が $60 \mathrm{pg} / \mathrm{dL}$ 未満になった時の VitD の減量基準 がない点が本プロトコールの問題点の一つであり，今 後改良が必要である。 また研究終了時 VitD の投与量 が ADVANCE study ${ }^{4)}$ での低用量 VitD 製剤に比べ, 多くなっており，透析液濃度の調整などが必要と考え られた．今後，Cina 投与量により Etel 開始量が変更 される必要があり，そのことにより，切り替えによる 低カルシウム血症の発症などの副作用の予防に有効と 考えられる. また今後, Cinaに比べアドヒアランスの 向上が期待されるエボカルセトとの検討も必要と考え られる。

\section{結語}

今回 Etel 投与プロトコールを作成した. Etelによる SHPT の管理は，医療費用面でやや高価となる可能性 はあるが, 強力な治療方法である可能性が考えられた。

$\mathrm{COI}$ : 阿部貴弥：小野薬品工業株式会社（講演料), 他の 共著者は開示すべきものなし.
文献

1）日本透析医学会統計調查委員会. 図説 わが国の慢性 透析療法の現況（2016 年 12 月 31 日現在)。東京：日 本透析医学会, 2017.

2）日本透析医学会. 慢性腎臟病に伴う骨・ミネラル代謝 異常の診療ガイドライン. 透析会誌 2012；45：301-56.

3) Taniguchi M, Fukagawa M, Fujii N, et al. Serum phosphate and calcium should be primarily and consistently controlled in prevalent hemodialysis patients. Ther Apher Dial 2013; 17: 221-8.

4) Raggi P, Chertow GM, Torres PU, et al. The ADVANCE study: a randomized study to evaluate the effects of cinacalcet plus low-dose vitamin D on vascular calcification in patients on hemodialysis. Nephrol Dial Transplant 2011; 26: 1327-39.

5) The EVOLVE Trial Investigators, Chertow GM, Block GA, Correa-Rotter R, et al. Effect of cinacalcet on cardiovascular disease in patients undergoing dialysis. N Engl J Med 2012; 367: 2482-94.

6) Ureña-Torres PA, Floege J, Hawley CM, et al. Protocol adherence and the progression of cardiovascular calcification in the ADVANCE study. Nephrol Dial Transplant 2013; 28: 146-52.

7) The EVOLVE Trial Investigators, Wheeler DC, London GM, Pelfrey PS, et al. Effects of cinacalcet on atherosclerotic and nonatherosclerotic cardiovascular events in patients receiving hemodialysis: the EValuation Of Cinacalcet $\mathrm{HCl}$ Therapy to Lower CardioVascular Events (EVOLVE) trial. J Am Heart Assoc 2014; 3: e001363.

8) Floege J, Kubo Y, Floege A, Chertow GM, Parfrey PS. The Effect of Cinacalcet on Calcific Uremic Arteriolopathy Events in Patients Receiving Hemodialysis: The EVOLVE Trial. Clin J Am Soc Nephrol 2015; 10: 800-7.

9) パーサビブインタビューフォーム，2017 年 2 月改訂 (第 2 版)

10) Payne RB, Little AJ, Williams RB, Milner JR. Interpretation of serum calcium levels in patients with abnormal serum proteins. Br Med J 1973; 4: 643-6.

11) Block GA, Bushinsky DA, Cheng S, et al. Effect of Etelcalcetide vs Cinacalcet on Serum Parathyroid Hormone in Patients Receiving Hemodialysis With Secondary Hyperparathyroidism: A Randomized Clinical Trial. JAMA 2017; 317: 156-164. 